\title{
Інноваційна діяльність підприємств як системоутворюючого складника механізму сталого інноваційного розвитку національної економіки
}

\author{
Анна Ворона * А \\ А Черкаський національний університет імені Богдана Хмельницького, бульвар Шевченка, 81, Черкаси, 18000, Україна
}

Received: December 12, 2020 | Revised: December 24, 2020 | Accepted: December 31, 2020

DOI: $10.33445 /$ sds.2020.10.6.19

\begin{abstract}
Анотація
У статті розглянуто окремі складові інноваційного механізму національної економіки, їх функції та основні завдання. Досліджена роль підприємств як системоутворюючого складника сталого інноваційного розвитку національної економіки.

Висвітлено рівень зацікавленості підприємств у веденні інноваційної діяльності, розглянуто фактори, що впливають на зацікавленість підприємств інноватизацією виробничого процесу. Проаналізовано джерела фінансування інноваційної діяльності підприємств, досліджена структура фінансування інноватизації у період 2012-2018 рр. За результатами дослідження виявлено: здійснення інноваційної діяльності доцільне лише у разі ії прибутковості, яка перевищує прибутковість традиційних підходів різних видів економічної діяльності.

Зазначено, що кредитування інноваційної діяльності, яке у багатьох країнах $€$ фінансовою основою інноваційних процесів, в Україні гальмується, зокрема, обмеженим обсягом довгострокових ресурсів, високою вартістю інноваційного банківського кредитування, відсутністю непрямої підтримки у вигляді знижених ставок для інноваційно зацікавлених підприємств. Венчурне інвестування, франчайзинг, індустріальні та технопарки в Україні перебувають на етапі початкового розвитку.

Розглянуто процес трансферу технологій як основного показника ефективності діяльності науково-технічної сфери економічної діяльності, законодавчу складову його існування та методологію державної підтримки. Проведено аналіз динаміки обсягів трансферу технологій у період 2012-2018рр., зроблено висновок про активізацію інноватизації у сферах енергетики, наноматеріалів і технологій, охорони природнього середовища, інформаційно-комунікаційних технологій, а також зниження рівня інноваційної діяльності у сфері транспорту, медицини та АПК.
\end{abstract}

Ключові слова: інноваційна діяльність, державна інноваційна політика, сталий інноваційний розвиток, національна економіка, підприємства.

\section{Постановка проблеми}

Перехід до сталого інноваційного розвитку національної економіки вже тривалий час визнаний науковою спільнотою як необхідність для ії подальшого розвитку в умовах високої конкуренції. Світові стандарти, створення нових та посилення інноваційних позицій наявних ринків актуалізують перегляд існуючих механізмів управління ринковими процесами та виводять на передній план прискорення інноватизації у всіх сферах економічної діяльності.

Успіх переходу до сталого інноваційного розвитку національної економіки залежить від дієвості й результативності кожного з системоутворюючих чинників, адже йдеться, без сумніву, про цілісну систему складників,

\footnotetext{
*Corresponding author: аспірант кафедри менеджменту та економічної безпеки, e-mail: 19anna_crow94@ukr.net
} 
механізмів, емерджентні наслідки зв'язків яких створюють нові умови для діяльності та розвитку учасників економічних відносин.

Отже, інноваційність вітчизняної економіки забезпечується механізмами, що передбачають взаємодію держави, бізнесу, виробників інновацій, інвесторів, посередників на законодавчих, інформаційних, партнерських тощо засадах. Ефективність кожного зі складників інноваційної системи визначається цілями, функціями, повноваженнями, закладеними в основу діяльності кожного 3 них, єдиновекторністю, а також взаємовідповідальністю за утворені та емерджентні зв'язки. Сталий інноваційний розвиток національної економіки має на меті як активізацію і модернізацію цих зв'язків, так і повноцінну віддачу кожного 3 системоутворюючих чинників. На цій основі важливим $\epsilon$ дослідження стимулювання інноваційної активності суб'єктів господарювання та їх адаптивності до вимог ринку.

\section{Аналіз останніх досліджень та публікацій}

Згідно з дослідженнями, проведеними Я. Йовенко, актуальним $€$ питання створення системи венчурного фінансування інноваційної діяльності [1]. Питання фінансового забезпечення інноваційної діяльності знайшло місце в дослідженнях В. Фоміних [2], О. Амоша,
А. Потовюка, С. Ілляшенко, О. Юркевича, І. Епіфанової [3]. Також Г. Возняком, В. Зянько [4] розглядалися роль венчурних фондів у фінансовому забезпеченні інноваційної діяльності підприємств.

\section{Постановка завдання}

Метою статті $\epsilon$ висвітлення інноваційної діяльності підприємств як системоутворюючого складника механізму сталого інноваційного

розвитку національної економіки.

\section{Виклад основного матеріалу}

Системоутворюючі складники механізму сталого інноваційного розвитку, їх функції та основні завдання подано на рис. 1. У даній статті автор вважає за доцільне зупинитися на інноваційній активності підприємницького сектора (бізнесу) та окремих посередникахінституціях як забезпечуючої основи інноваційного розвитку національної економіки.

Дослідження зацікавленості підприємств в інноваційній модернізації виробництва демонструють низький рівень активізації інноватизації. Це зумовлено, зокрема, недостатністю власних коштів підприємств для проведення інноваційної діяльності, високими витратами на інновації, труднощами в отриманні субсидій для реалізації інноваційних проектів, відсутністю доступних кредитів. Натомість, інвестиції спрямовуються на модернізацію підприємств та організацій шляхом екстенсивного розвитку, що передусім втілено у пріоритетності кількісної складової над якісною.

Незважаючи на коливання обсягів фінансування інноваційної діяльності протягом вказаного періоду, головним джерелом фінансової підтримки інноваційної діяльності $€$ власні кошти підприємств як найбільш зацікавлених учасників ринкових відносин (табл. 1).

Важливо зазначити, що обсяг фінансування інновацій вітчизняними інвесторами суттєво зростає, тоді як іноземні інвестори втрачають свою зацікавленість інноваційною продукцією України. Суттєве зниження інновацій за рахунок кредитування $\epsilon$ свідченням ускладненої та несприятливої кредитної політики уряду й відповідного регулювання. Низька ефективність залучення іноземних інвестицій для розвитку інноватизації національної економіки підтверджується загальною тенденцією до зменшення обсягів такого інвестування в Україні. 


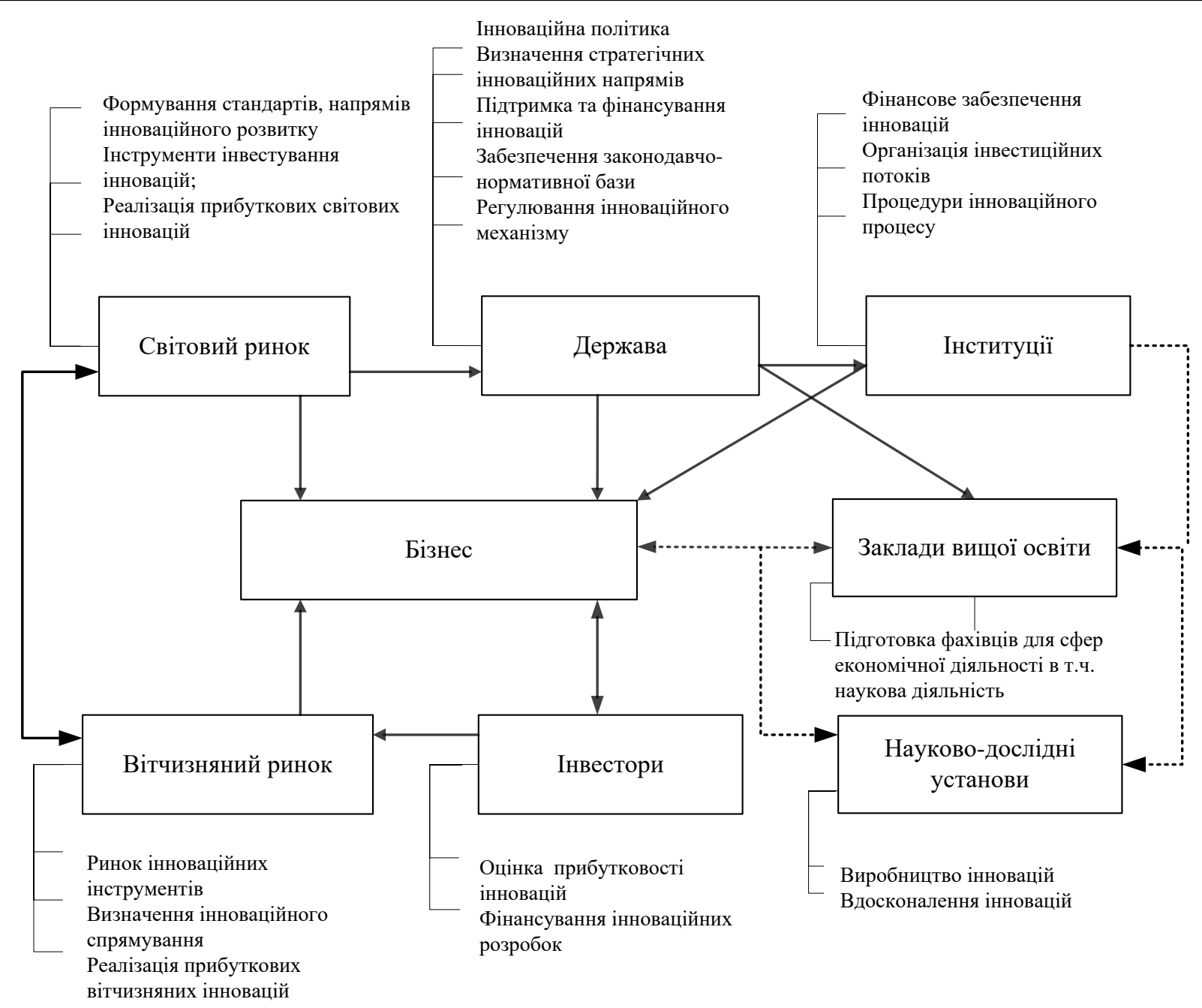

Рис. 1. Інноваційний механізм національної економіки Джерело: Розроблено автором

За статистичними даними, частка складала 8,3\%, у 2018 р. - 0,9\%. При цьому, фінансування інноваційного розвитку найнижчою часткою іноземного інвестування в економіки іноземними інвесторами у 2012 р. економіку $є 0,1 \%$ у 2016 р. (рис. 2).

Таблиця 1 - Обсяги фінансування інноваційної діяльності за джерелами у 2012-2018 рр.

\begin{tabular}{|l|c|c|c|c|}
\hline & 2012 p. & 2014 p. & 2016 p. & 2018 p. \\
\hline Усього & 11480,1 & 7695,9 & 23229,5 & 12180,1 \\
\hline Власні кошти підприємств & 7335,8 & 6540,3 & 13427,0 & 10742,0 \\
\hline Державний бюджет & 224,3 & 334,1 & 55,1 & 639,1 \\
\hline Місцеві бюджети & 17,6 & 5,7 & 38,4 & 13,4 \\
\hline Вітчизняні інвестори & 15,4 & 8,2 & 74,3 & 109,7 \\
\hline Іноземні інвестори & 994,8 & 138,7 & 58,6 & 106,9 \\
\hline Кредити & 2407,8 & 561,1 & 113,7 & 473,9 \\
\hline Інші джерела & 345,8 & 64,9 & 46,6 & 95,0 \\
\hline
\end{tabular}

Джерело: Складено авторкою на основі [5] 
Поряд із цим у період 2012-2018 рр. частка самофінансування інновацій зросла з 63,9\% (у 2012 р.) до $88,2 \%$ (у 2018 р.), тоді як обсяги фінансування інновацій 3 інших джерел (місцеві бюджети, іноземні інвестори, кредитування, інші джерела) суттєво зменшилися. I це - на фоні темпів інфляції за відповідний період та активного зростання цін. Варто зазначити, що найбільшою була частка самофінансування інноваційно активних підприємств у 2016 р. (94,9\%) (рис. 3).

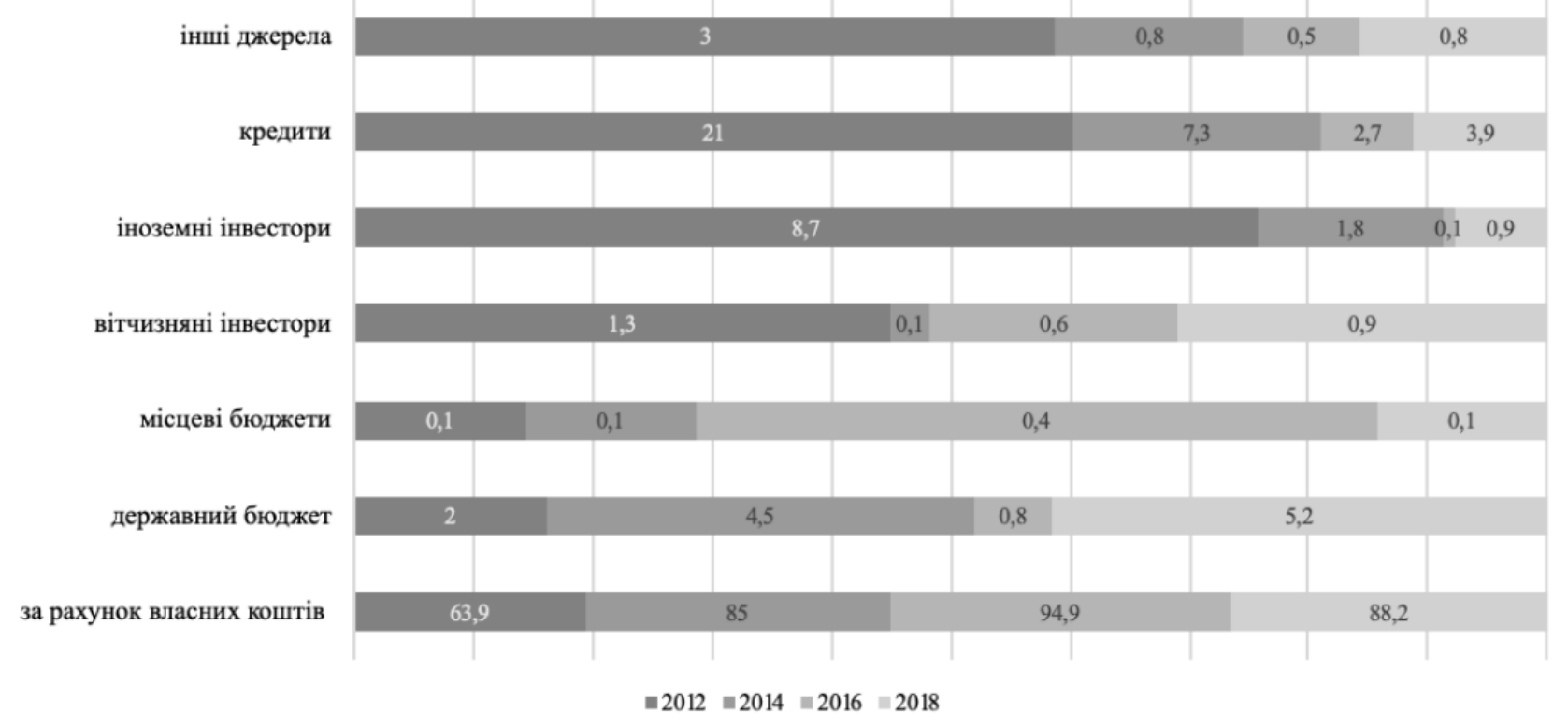

Рис. 2. Структура джерел фінансування інноваційної діяльності у 2012-2018 рр., \% Джерело: Складено авторкою на основі [5]

Система фінансового забезпечення інноваційної діяльності характеризується високими інвестиційними ризиками втрати вкладеного капіталу. Як наслідок, здійснення інноваційної діяльності доцільне лише у разі іiі прибутковості, що перевищуватиме прибутковість традиційних підходів різних видів економічної діяльності. Загальний обсяг фінансування інноваційної діяльності формується значною мірою за власні кошти та меншою мірою - за рахунок кредитів банків та інших форм інвестування.

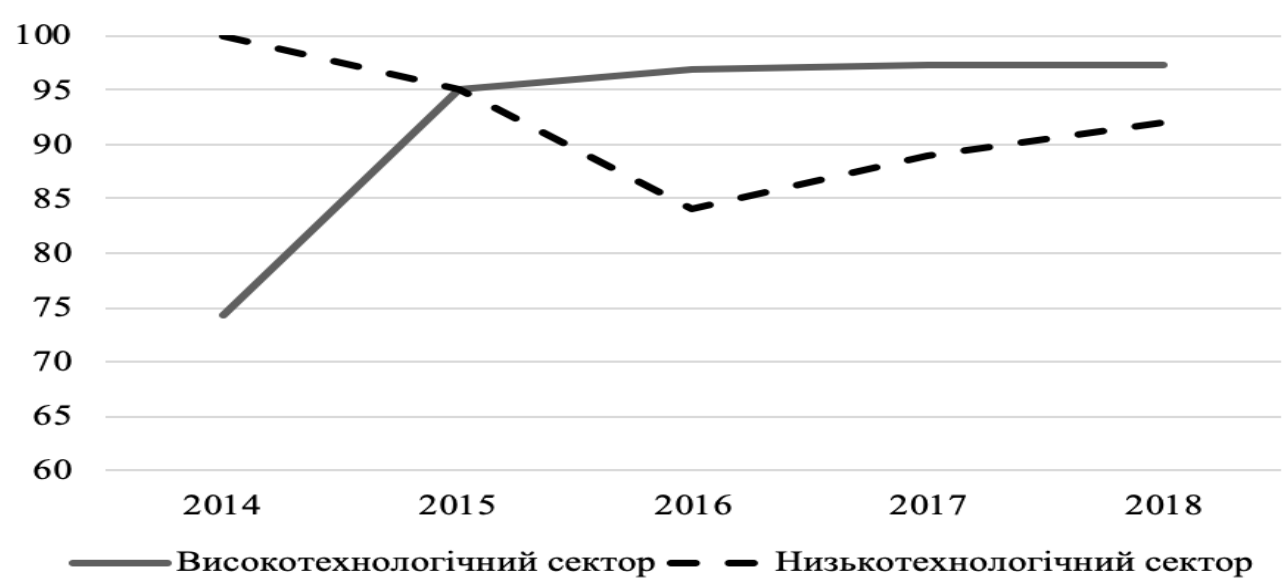

Рис. 3. Динаміка обсягів фінансування інноваційної діяльності за рахунок власних коштів підприємств за технологічними секторами у 2014-2018 рр. (у \% до загального обсягу фінансування відповідного сектору) Джерело: Складено авторкою на основі [5] 
Самофінансування інноваційної діяльності має ряд переваг порівняно 3 іншими джерелами: відсутність посередників, а відтак - можливість швидкого інвестування в інновації; відсутність фактичного витоку коштів за межі підприємства; відсутність додаткових витрат (виплата кредитних відсотків); можливість швидкого прийнятя інвестиційних рішень; мобільність обігу грошових коштів; уникнення ризику банкрутства та неплатоспроможності В процесі реалізації інноваційного проекту. Певним чином самофінансування інноваційної діяльності підприємства сприяє його розвитку, не вимагає додаткових витрат, а також дає змогу обійти бюрократичні інстанції перед безпосереднім початком інноватизації підприємства. На жаль, інноваційно зацікавлені суб'єкти економічних відносин часто не мають фінансової та організаційної можливості самостійно забезпечити фінансову складову інноваційного процесу на виробництві.

Інноваційний розвиток підприємництва забезпечується через ряд установ і організацій, які охоплюють фінансовий, організаційний, інституційний тощо аспекти. Діяльність цих установ щодо інноваційного процесу характеризуються наступними даними.

Фінансово-кредитні установи. Протягом 2012-2018 рр. спостерігається стрімке зниження частки кредитування інноваційних проектів. Протягом досліджуваного періоду частка кредитування зменшилася на 17\% (з 21\% у 2012 р. до 3,9\% у 2018 р.). 3більшення частки банківських кредитів спостерігалось у секторі середньонизько- та середньовисокотехнологічного виробництва - на 16,6 та 35,8\% відповідно за рахунок кредитного фінансування виробництва гумових і пластмасових виробів (у сумі 107,4 млн грн) та електричного устаткування (213,1 млн грн). У високотехнологічному секторі кредитні кошти отримали лише підприємства з виробництва основних фармацевтичних продуктів і фармацевтичних препаратів, але у 10 разів менше порівняно з 2015 роком - 3,1 млн грн. Частка кредитів для інновацій у загальному обсязі банківського кредитування складає від 0,02\% у 2015 р. до 0,12 у 2018 р. Величина облікової ставки НБУ протягом періоду дослідження (в середньому 12,5\%) зумовлювала низьку частку довгострокових кредитів, спрямованих в інвестиційну діяльність (у межах 22,0-19,5\% у 2015-2017 роках) і високу вартість кредитних коштів (середньозважена відсоткова ставка у 2015 році становила $21,81 \%$, у 2016 році - 17,14\%, а у 2017 - знизилася до 12,8\%), адже фактична ставка процента кредитування перебуває на рівні 20\% річних та має тенденцію до зростання $[6$, c. 183, 185].

Для позичальників певною перевагою може слугувати можливість погашення кредиту поступово та відсутність його оподаткування. Водночас кредити підвищують відповідальність до впровадження інновацій, оскільки $\epsilon$ обов'язковими для погашення. Інноватизація виробництва супроводжується низкою ризиків, особливо на початковому етапі. Як наслідок, кредитування інноваційної діяльності $є$ ризиковим, тому процентні ставки банків на надані кредити не можуть цілком задовольнити потреби об'єктів інноваційної діяльності, оскільки плата за кредит часто неспівставна 3 можливими результатами діяльності виробництва після використання отриманого кредиту.

Гальмівними факторами у популяризації кредитування інноваційної діяльності $\epsilon$ : обмежений обсяг довгострокових ресурсів, висока вартість інноваційного банківського кредитування порівняно з іншими кредитними напрямками комерційних банків, відсутність непрямої підтримки у вигляді знижених ставок для фінансування інноваційно зацікавлених підприємств, нестабільність соціоекономічного становища країни, що значною мірою впливає на розмір відсоткових ставок, недовіра до банківської системи України, значний розмір ставки рефінансування НБУ, складнощі отримання доступу до такого фінансування та загальні умови надання кредитів.

Венчурні фонди, як один із способів забезпечити інноваціями підприємницький 
сектор, $€$ доволі популярним у світі, але в Україні активного поширення не набув. Найпривабливішими напрямами венчурного інвестування за 2014-2016 рр. стали: онлайнпослуги - 16 угод на загальну суму 55 млн. грн. (9 млн. дол. на посівній стадії), програмне забезпечення - 12 млн. грн., мобільний зв'язок - 9 млн. грн. [7, с. 396].

Щодо франчайзингу, то цей вид стимулювання інноваційної діяльності на українському ринку нині тільки набирає обертів. Кількість компаній-франчайзерів за період 2001-2018 рр. зросла більше ніж у 10 разів (до 504 у 2018 р.). Структура ринку представлена такими даними: 83,8\% усіх точок працюють на ринку франчайзингу у сфері роздрібної торгівлі, 72,7\% - у сфері послуг та 70,4\% - у ресторанному бізнесі [8].

Індустріальні парки, технопарки. Важливим системоутворюючим чинником механізму сталого інноваційного розвитку національної економіки, що діє як акселератор інноваційного процесу у багатьох розвинених країнах, є технологічні парки. Зважаючи на важливість таких об'єднань для ефективного інноваційного розвитку, урядом країн запроваджуються спеціальні режими стимулювання ефективної діяльності технологічних парків. Впроваджувані проекти містять податкові та митні пільги, цільове фінансування окремих інноваційних проектів, пільгове кредитування тощо. За такої державної підтримки технологічні парки у світі створюють робочі місця, забезпечують конкурентоспроможність окремих сфер економічної діяльності на внутрішньому та зовнішньому ринках, а також наповнюють ринок інноваційними продуктами та послугами.

В Україні загалом діє 16 технопарків. За даними Міністерства освіти і науки за період існування технопарків в Україні (2000-2018рр.) на базі технопарків загалом реалізовано 120 інноваційних проектів, створено 3500 робочих місць, вироблено інноваційної продукції на 13 млрд грн і перераховано до бюджету 1,3 млрд грн. Для порівняння: у Чехії після появи індустріальних парків у 1998 році інвестори за сім років вклали в них понад 9 млрд євро. А в Південній Кореї індустріальні парки забезпечують 80\% експорту всієї країни.

Державну реєстрацію технопарків проводить Міносвіти, причому вона можлива лише у разі успішного проходження спеціальної експертизи [9]. Загалом діяльність індустріальних і технопарків в Україні не аналізується та статистично не фіксується. Ці потужні складники механізму сталого інноваційного розвитку практично нерозвинені. Нині в Україні розвиток технопарків ускладнено: починаючи від реєстрації кожного нового парку до складної експертизи його ефективності.

В Україні на даний момент не існує екотехнопарків, які мають значний інноваційний потенціал і здатні стати одним з потужних інструментів сталого інноваційного розвитку національної економіки (рис. 4).

За даними Міністерства розвитку економіки, торгівлі і сільського господарства, в Україні у 2019 р. було зареєстровано 42 індустріальні парки. Але тільки у 12 з них є реально створені підприємства, що працюють. А у 25 індустріальних парках досі відсутні керуючі компанії, які відповідають за їхнє функціонування [9].

Критерієм аналізу ефективності діяльності науково-технічної сфери, а також ефективності iii регулювання $\epsilon$ трансфер технологій як ключова складова реалізації пріоритетних напрямів інноваційної діяльності.

Трансфер технологій $є$ однією з ключових складових реалізації пріоритетних напрямів інноваційної діяльності (як і їх фінансування), який за Законом України «Про державне регулювання діяльності у сфері трансферу технологій» передбачає передачу технології, створеної за результатами науково-технічної діяльності. Також з метою сприяння ефективному розвитку науково-дослідної сфери економічної діяльності у 2016 р. Верховною Радою України було прийнято Закон "Про наукову і науково-технічну діяльність", чинною $€$ редакція від 16 листопада 2019 р. 


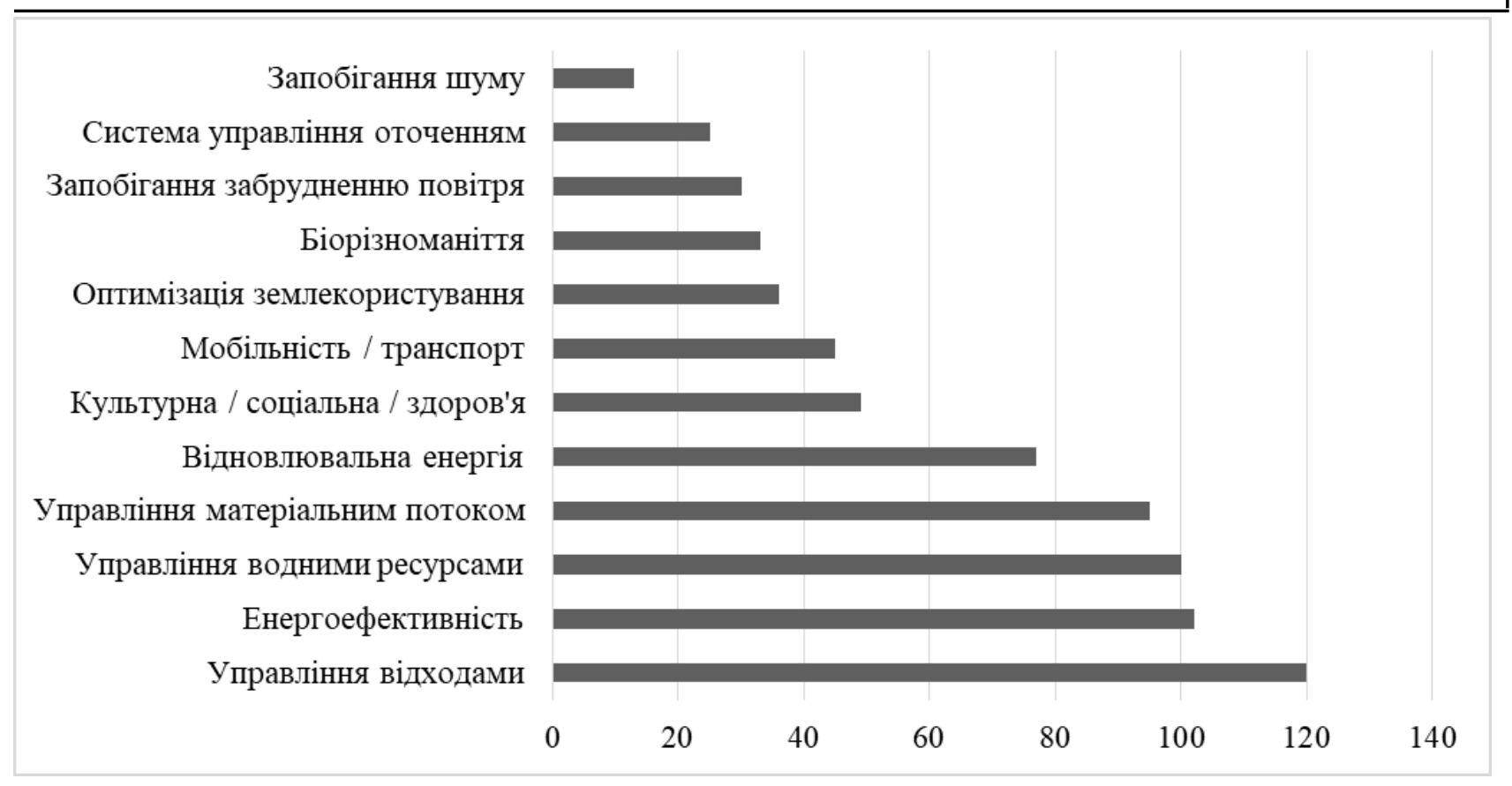

Рис. 4. Кількість еко-інновацій у еко-технопарках світу в натуральному вираженні у 2018 р., шт.

Джерело: Розроблено авторкою за джерелом [10]

Цей закон регламентує засади фінансового забезпечення наукової i науково-технічної діяльності, зокрема внесені пропозиції щодо напрямів забезпечення за рахунок базового фінансування основної діяльності державних наукових установ, пріоритетних напрямів на отримання грантів, бюджетних програм сприяння розвитку виробничо-орієнтованих наукових установ. Визначені джерела отримання фінансування: кошти державного та місцевого бюджетів, а також коштів установ, організацій та підприємств, вітчизняних та іноземних замовників робіт, грантів, інших джерел, не заборонених законом [11]. Передбачено існування фондів грантової підтримки наукових досліджень і науково-дослідних розробок, Національного фонду досліджень України, створеного 3 метою стимулювання фундаментальних та прикладних наукових досліджень, грантова підтримка пріоритетних напрямків науковотехнічної діяльності та забезпечення цільового, ефективного та раціонального використання коштів фонду, сформованих за рахунок державного бюджету, добровільних внесків та інших джерел, не заборонених законом.

За Стратегічними пріоритетами 2018 р. [12] (напрямами інноваційної діяльності підприємств, які підтримуються державою) було передано 1831 створену за рахунок бюджетного фінансування технологію, у 2017 р. -1798 (рис. 5).

Найбільшою стала частка надходжень за стратегічним пріоритетом "Розвиток агропромислового комплексу" (39,6\%), при цьому зросли також частки надходжень за напрямками "Широке застосування технологій більш чистого виробництва та охорони навколишнього середовища" (на 11,7 в.п.) та “Освоєння виробництва

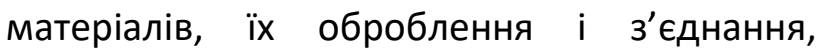
створення індустрії наноматеріалів та нанотехнологій" (на 7,4 в.п.). 


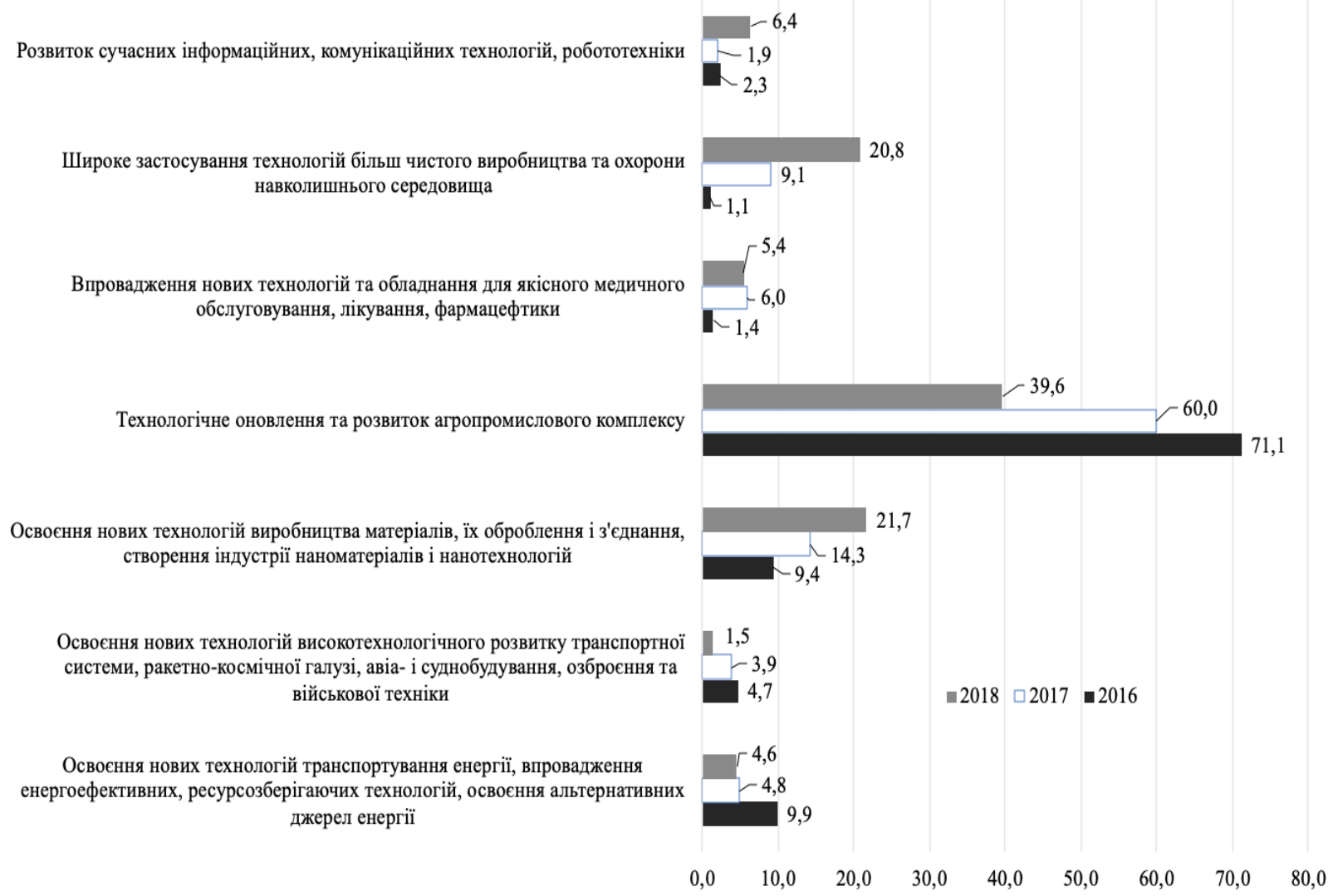

Рис. 5. Частка надходжень від передання нових технологій за стратегічними пріоритетами у 2016-2018 рр., \%

Джерело: Сформувала авторка за джерелом [13]

Проаналізовані показники дозволяють зробити висновок про активізацію інноватизації у сфері енергетики, наноматеріалів і технологій, охорони природнього середовища, інформаційнокомунікаційних технологій, а також зниження рівня інноваційної діяльності у сфері транспорту, медицини та АПК.

Розглянемо обсяги надходжень від передання нових технологій та/або права на використання об'єктів права інтелектуальної власності за стратегічними пріоритетними напрямами та за формами передання у 20162018 рр. (табл. 2).

Збільшився загальний обсяг надходжень від передання технологій і у 2018 р. та становив 96,06 млн грн (на 21,2\% порівняно 3 2017 р.). При цьому найбільшу частку отримано за 4-м стратегічним пріоритетом "Технологічне оновлення та розвиток агропромислового комплексу" (39,6\%), за яким передано також найбільшу частку технологій (40\%). Найменша частка (1,5\%) була отримана за стратегічним пріоритетом 2 “Освоєння нових технологій високотехнологічного розвитку транспортної системи, ракетно-космічної галузі, авіа- і суднобудування, озброєння та військової техніки", а також передано найменшу частку технологій $(0,4 \%)$.

Загалом, передання технологій здійснювалося чотирма розпорядниками на зовнішньому (57 од. або 14,1\% - за шістьма, крім 2-го, пріоритетами) та внутрішньому (1774 од. або 85,9\% - за всіма пріоритетами) ринках. Найбільшу частку переданих технологій здійснено МОН (969 од. або $52,9 \%)$ НАAН (613 од. або 33,5\%), Мінприроди (211 од. або 11,5\%), найменша припадає на НАН (38 од. або 2,1\%). Передання технологій на зовнішньому ринку не здійснювалося лише Мінприроди та НАAН. 


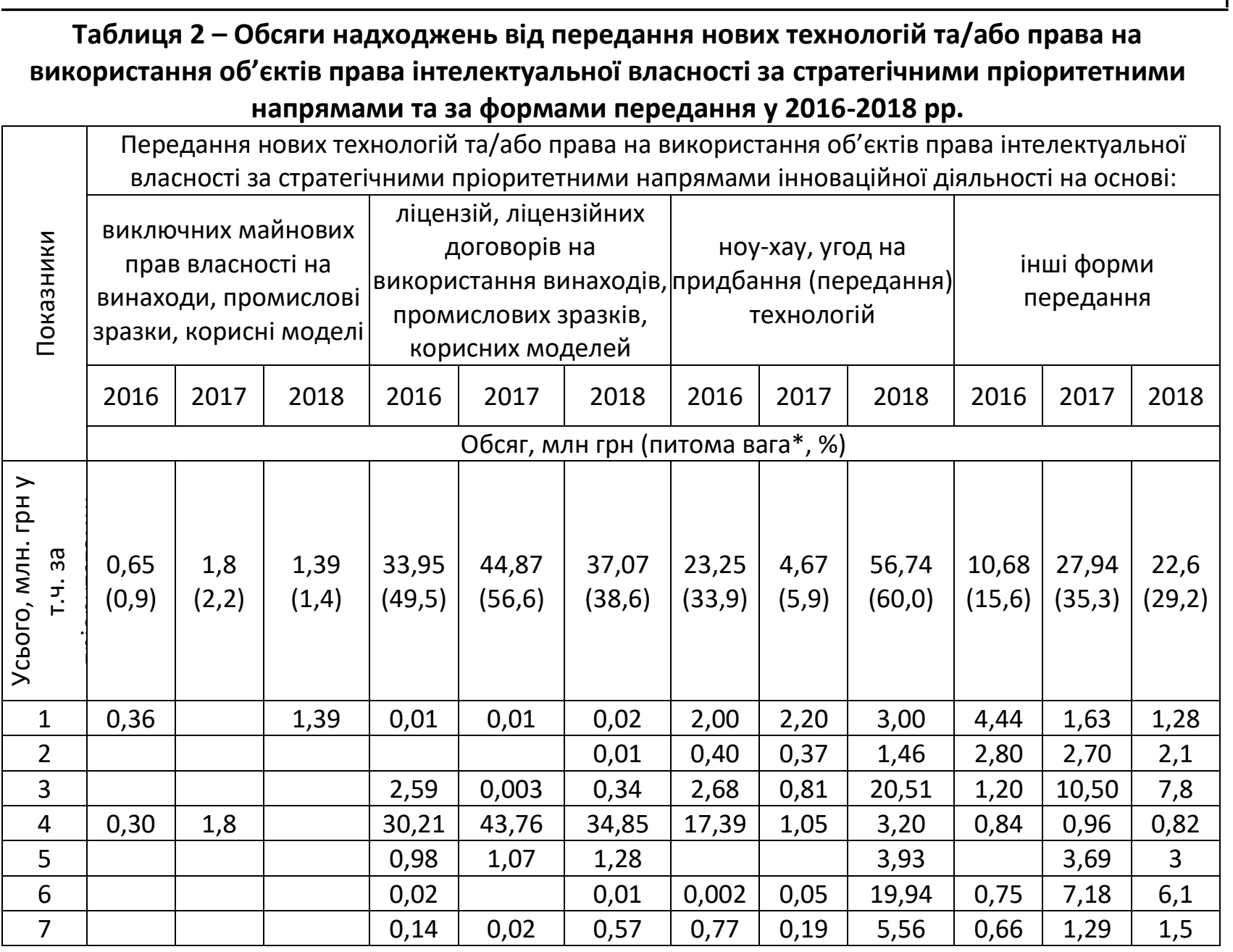

Джерело: Сформувала авторка за джерелом [13]

На зовнішньому ринку технології передавалися за видами договорів: “Ліцензії, ліцензійні договори на використання винаходів, промислових зразків, корисних моделей" (37,6\%) та "Ноу-хау, угоди на придбання (передання) технологій" (62,4\%). На внутрішньому ринку видом договору «Виключні майнові права власності на винаходи, промислові зразки, корисні моделі» НААН було передано 1 технологія або 1,8\% за першим пріоритетом та 56 технологій або 98,2\% - за видом договору "Ноу-хау, угоди на передання технологій".

Порівняно з 2017 р., у 2018 р. на внутрішньому ринку збільшилася кількість переданих технологій на 1,7\% та на 9,5 \% обсяг отриманих від передання коштів. При цьому відбулося зменшення частки переданих коштів у загальних обсягах (на 9,3 в.п.), що свідчить про підвищення попиту на інноваційні технології на внутрішньому ринку.

На зовнішньому ринку у 2018 р., у порівнянні з 2017 р., збільшилась кількість переданих технологій на 5,6\% та 3,5 рази обсягу отриманих від передання коштів. Також збільшилася частка переданих коштів в загальних обсягах (на 9,3 в. п.). Таке підвищення свідчить про активізацію трансферу технологій через підвищення конкурентоспроможності української продукції.

Також результати аналізу отриманих статистичних даних відображають активізацію процесу трансферу технологій у таких сферах:

енергетика (1-й стратегічний пріоритет); транспорт (2-й стратегічний пріоритет);

наноматеріали та нанотехнології (3-й стратегічних пріоритет);

АПК (4-й стратегічний пріоритет); медицина (5-й стратегічний пріоритет); 
охорона природного середовища (6-й стратегічний пріоритет);

IKT (7-й стратегічний пріоритет).

Зауважимо, що перехід до сталого інноваційного розвитку національної економіки неможливо здійснити, забезпечивши лише декларативну частину дії механізму. Більш важливим для реалізації поставлених завдань $\epsilon$ ефективність інноватизації, як такої, та переходу на відповідну модель розвитку для підприємництва, яке не здійснюватиме жодних інновацій без чіткого усвідомлення їх ефективності, підтвердженої розрахунками. Зазначена складова механізму має передбачати оцінку як ефективності інноваційної діяльності загалом, так і кожного із системоутворюючих чинників через систему оцінки коштів, вкладених в інновації.

\section{Висновки}

Таким чином, висвітлення інноваційної діяльності підприємств як системоутворюючого складника механізму сталого інноваційного розвитку національної економіки демонструє наступне:

1) головним джерелом фінансової підтримки інноваційної діяльності $€$ власні кошти підприємств як найбільш зацікавлених учасників ринкових відносин. Низька ефективність залучення іноземних інвестицій для розвитку інноватизації національної економіки обумовила найнижчу частку цього джерела серед інших. Система фінансового забезпечення інноваційної діяльності характеризується високими інвестиційними ризиками втрати вкладеного капіталу. Як наслідок, здійснення інноваційної діяльності доцільне лише у разі її прибутковості, що перевищуватиме прибутковість традиційних підходів різних видів економічної діяльності;

2) стимулююча діяльність установ і організацій, які $€$ посередниками в інноваційному процесі та забезпечують фінансовий, організаційний, інституційний тощо аспекти $\epsilon$ слабкою. Гальмівними факторами у популяризації кредитування інноваційної діяльності є: обмежений обсяг довгострокових ресурсів, висока вартість інноваційного банківського кредитування, відсутність непрямої підтримки у вигляді знижених ставок для інноваційно зацікавлених підприємств тощо. Венчурне інвестування, франчайзинг, індустріальні та технопарки в Україні перебувають на етапі початкового розвитку;

3) досліджено трансфер технологій. Активізація інноватизації спостерігається у сфері енергетики, наноматеріалів i технологій, охорони природнього середовища, інформаційно-комунікаційних технологій; зниження рівня інноваційної діяльності - у сфері транспорту, медицини та АПК. Передання технологій здійснюється чотирма розпорядниками на зовнішньому та внутрішньому ринках. Найбільшу частку переданих технологій здійснено МOH, НАAH, Мінприроди. Механізм передання технологій штучно ускладнений та потребує корегування, передусім, в частині організаційної структури, функцій, повноважень і завдань.

\section{Список використаних джерел}

1. Йовенко Я. Государственная инновационная политика. Бизнес. 2011. № 34. С. 44-55.

2. Фоміних B.І., Махова Н.І., Самохліб О.І. Проблеми фінансування інноваційної діяльності підприємств. Молодий вчений. 2017. № 10 (50). С.1089-1092.
3. Єпіфанова І. Ю. Аналіз ефективності управління фінансовим забезпеченням інноваційної діяльності вітчизняних підприємств. Управління соціальноекономічними трансформаціями господарських процесів: реалії і виклики : матеріали II Міжнародної науково- 
практичної інтернет-конференції, м. Мукачево, 6-7 квітня 2020 р. Мукачево: МДУ, 2020. 340 c. C. 268-272. URL : http://ir.lib.vntu.edu.ua//handle/123456789/ 29820

4. Зянько В. В. Сутність та джерела фінансового забезпечення інноваційної діяльності малих підприємств. Вісник Вінницького політехнічного інституту. 2015. № 5. С. 57-62. URL : http://nbuv.gov.ua/UJRN/vvpi_2015_ 5_11.

5. Статистичні збірники «Наукова та інноваційна діяльність в Україні» за 20122018 pp. URL : www.ukrstat.gov.ua/

6. Абрамова А., Марич М., Попова Л. Кредитне забезпечення інноваційного розвитку економіки банківськими установами в Україні. Проблеми і перспективи економіки та управління. 2019. № 2 (18). С. 180-189.

7. Мордань, Є.Ю. Венчурне інвестування в Україні та світі: сучасні тенденції та особливості розвитку. Інфраструктура ринку. Причорноморський науководослідний інститут економіки та інновацій. 2018. № 17. С. 391-399. URL : https://essuir.sumdu.edu.ua/bitstreamdownload/123456789/69708/1/Mordan_vent ure_financing.pdf

8. Франшизы в Украине устойчивы к кризису. Общий обзор сектора франчайзинга и его показатели на основе анкетирования. Специальный отчет Коммерческая служба США. Киев, 2015. URL : https://franchisegroup.com.ua/bitrix/templat es/nakitel_tpl/img/pdf/Franchise\%20Business
\%200utlook\%20Report.pdfa/bitrix/templates/ nakitel_tpl/img/pdf/Franchise\%20Business\%2 0Outlook\%20Report.pdf (дата звернення 07 липня 2020).

9. Харламов П. Місце сили: навіщо Україні індустріальні та технопарки. MIND URL : https://mind.ua/publications/20204723misce-sili-navishcho-ukrayini-industrialni-tatehnoparki (дата звернення 07 липня 2020).

10. Вигідне взаємодоповнення як крок вперед: аналіз ринку екотехнопарків в 2017-2019 рр. Pro-consulting.ua [Електронний ресурс]. URL : https://pro-consulting.ua/ua/pressroom/ vygodnoe-vzaimodopolnenie-kak-shagvpered-analiz-rynka-ekotehnoparkov-v-20172019-gg (дата звернення 10 липня 2020).

11. Про наукову і науково-технічну діяльність : Закон України, редакція від 19.04.2020. / Верховна Рада України. URL https://zakon.rada.gov.ua/laws/show/84819\#Text (дата звернення 10 липня 2020).

12. Про схвалення Стратегії розвитку сфери інноваційної діяльності на період до 2030 року : Розпорядження кабінету міністрів України від 10 липня 2019 р. № 526-p. URL : https://zakon.rada.gov.ua/laws/show/5262019-р\#Text (дата звернення 11 липня 2020).

13. Писаренко Т. В., Кваша Т. К. Стан інноваційної діяльності та діяльності у сфері трансферу технологій в Україні у 2018 році. Аналітична довідка. Київ, УкрIHТЕІ. 2019. 80 c. URL : https://mon.gov.ua/storage/app/ media/innovatsii-transfer-tehnologiy/2019/ 07/03/stan-innov-diyaln-2018f.pdf. (дата звернення 11 липня 2020).

\section{Инновационная деятельность предприятий как системообразующего компонента механизма устойчивого инновационного развития национальной экономики}

\footnotetext{
Анна Ворона * А

*Corresponding author: аспирант кафедры менеджмента и экономической безопасности, e-mail: 19anna_crow94@ukr.net А Черкасский национальный университет имени Богдана Хмельницкого, бульвар Шевченко, 81, Черкассы, 18000, Украина
}

\section{Аннотация}

В статье рассмотрены отдельные составляющие инновационного механизма национальной экономики, их функции и основные задачи. Исследована роль предприятий 
как системообразующего компонента устойчивого инновационного развития национальной экономики.

Освещены уровень заинтересованности предприятий в ведении инновационной деятельности, рассмотрены факторы, влияющие на заинтересованность предприятий инноватизации производственного процесса. Проанализированы источники финансирования инновационной деятельности предприятий, исследована структура финансирования инноватизации в период 2012-2018 гг. По результатам исследования выявлено: осуществление инновационной деятельности целесообразно лишь в случае его прибыльности, которая превышает прибыльность традиционных подходов различных видов экономической деятельности.

Отмечено, что кредитование инновационной деятельности, которое во многих странах является финансовой основой инновационных процессов, в Украине тормозится, в частности, ограниченным объемом долгосрочных ресурсов, высокой стоимостью инновационного банковского кредитования, отсутствием косвенной поддержки в виде пониженных ставок для инновационно заинтересованных предприятий. Венчурное инвестирование, франчайзинг, индустриальные и технопарки в Украине находятся на этапе начального развития.

Рассмотрен процесс трансфера технологий как основного показателя эффективности деятельности научно-технической сферы экономической деятельности, законодательную составляющую его существования и методологию государственной поддержки. Проведен анализ динамики объемов трансфера технологий в период 2012-2018 гг., сделан вывод об активизации инноватизации в сферах энергетики, наноматериалов и технологий, охраны природной среды, информационно-коммуникационных технологий, а также снижение уровня инновационной деятельности в сфере транспорта, медицины и АПК.

Ключевые слова: инновационная деятельность, государственная инновационная политика, устойчивое инновационное развитие, национальная экономика, предприятия.

\title{
Innovative activity of enterprises as a system-forming component of the mechanism of sustainable innovation development of the national economy
}

\author{
Anna Vorona * A \\ *Corresponding author: PhD student of the Department of Management and Economic Security, e-mail: 19anna_crow94@ukr.net \\ A Bohdan Khmelnytskyi Cherkasy National University, 81 Shevchenko Boulevard, Cherkasy, 18000, Ukraine
}

\begin{abstract}
The article considers some components of the innovation mechanism of the national economy, their functions and main tasks. The role of enterprises as a system-forming component of sustainable innovative development of the national economy is studied.

The level of interest of enterprises in conducting innovative activities is highlighted, the factors influencing the interest of enterprises in innovating the production process are considered. The sources of financing of innovative activity of enterprises are analyzed, the structure of financing of innovation in the period 2012-2018 is investigated.

It is noted that lending to innovation, which in many countries is the financial basis of innovation processes, in Ukraine is hampered, in particular, because of limited long-term resources, high cost of innovative bank lending, lack of indirect support in the form of reduced rates for innovation-interested enterprises. Venture investment, franchising, industrial and technology parks in Ukraine are at the stage of initial development.

The process of technology transfer as the main indicator of the efficiency of scientific and technical sphere of economic activity, the legislative component of its existence and the methodology of state support are considered. The dynamics of technology transfer in the period
\end{abstract}


2012-2018 is analyzed, the conclusion is made on the intensification of innovation in the fields of energy, nanomaterials and technologies, environmental protection, information and communication technologies, as well as reducing the level of innovation in transport, medicine and agriculture.

Keywords: innovation activity, state innovation policy, sustainable innovation development, national economy, enterprises.

\section{References}

1. Y"ovenko Ya (2011). Gosudarstvennaya y’nnovacy`onnaya poly`ty`ka [State innovation policy]. By`znes [Business]. No 34. pp. 44-55.

2. Fominy`x V.I., Maxova N.I. \& Samoxlib O.I. (2017) Problemy' finansuvannya innovacijnoyi diyal'nosti pidpry’yemstv [Problems of financing innovative activity of enterprises]. Molody 'j vcheny' $j$ [A young scientist]. No 10 (50). pp.1089-1092.

3. Yepifanova I. Yu. (2020) Analiz efekty vnosti upravlinnya finansovy'm zabezpechennyam innovacijnoyi diyal'nosti vitchy'znyany' $x$ pidpry`yemstv. Upravlinnya social'noekonomichny'my' transformaciyamy' gospodars'ky`x procesiv: realiyi i vy`kly`ky` [Analysis of the effectiveness of financial management of innovation of domestic enterprises. Management of socio-economic transformations of economic processes] : materialy` II Mizhnarodnoyi naukovoprakty`chnoyi internet-konferenciyi, $\mathrm{m}$. Mukachevo, 6-7 kvitnya 2020 r. [Materials of the II International scientific-practical Internet conference, Mukachevo, April 6-7, 2020]. Mukachevo: MDU, 2020. pp. 268-272. Available at: http://ir.lib.vntu.edu.ua//handle/123456789 /29820 (accessed 10.07. 2019).

4. Zyan `ko V. V. (2015) Sutnist' ta dzherela finansovogo zabezpechennya innovacijnoyi diyal'nosti maly'x pidpry'yemstv [The essence and sources of financial support for innovation of small enterprises]. Visny'k Vinny'cz`kogo politexnichnogo insty`tutu [Bulletin of Vinnytsia Polytechnic Institute]. No 5. p. 57-62. (accessed 13.07. 2019).

5. Staty`sty`chni zbirny`ky` «Naukova ta innovacijna diyal'nist' v Ukrayini» za 20122018 rr. [Statistical collections "Scientific and innovative activities in Ukraine" for 20122018]. Available at: www.ukrstat.gov.ua/ (accessed 10-15.07. 2019).

6. Abramova A., Mary`ch M. \& Popova L. (2019). Kredy'tne zabezpechennya innovacijnogo rozvy'tku ekonomiky' bankivs'ky'my' ustanovamy' v Ukrayini [Credit support for innovative economic development by banking institutions in Ukraine]. Problemy ' $i$ perspekty 'vy' ekonomiky' ta upravlinnya [Problems and prospects of economics and management]. No 2 (18). pp. 180-189.

7. Mordan', Ye.Yu. (2018). Venchurne investuvannya $v$ Ukrayini ta sviti: suchasni tendenciyi ta osobly vosti rozvy tku [Venture investment in Ukraine and the world: current trends and features of development]. Infrastruktura ry`nku. Pry`chornomors`ky`j naukovo-doslidny'j insty'tut ekonomiky' ta innovacij [Market infrastructure. Black Sea Research Institute of Economics and Innovation]. No 17. pp. 391-399. Available at: https://essuir.sumdu.edu.ua/bitstreamdownload/123456789/69708/1/Mordan_ve nture_financing.pdf

8. Franshy`zы v Ukray`ne ustojchy`vы k kry`zy`su. Obshhy`j obzor sektora franchajzy 'nga y` ego pokazately` na osnove ankety'rovany ya (2015). Specy al 'nuj otchet [Franchises in Ukraine are resistant to the crisis. An overview of the franchising sector and its indicators based on a questionnaire. Special report] Kommercheskaya sluzhba SShA [US Commercial Service]. Ky`ev. Available at: https://franchisegroup.com.ua/bitrix/templ ates/nakitel_tpl/img/pdf/Franchise\%20Busin ess\%200utlook\%20Report.pdfa/bitrix/templ ates/nakitel_tpl/img/pdf/Franchise\%20Busin ess\%200utlook\%20Report.pdf (accessed 
07.07. 2019).

9. Xarlamov P. (2020) Misce sy`ly: navishho Ukrayini industrial'ni ta texnoparky ' [Place of power: why Ukraine industrial and technology parks]. MIND (n. d.) Available at: https://mind.ua/publications/20204723misce-sili-navishcho-ukrayini-industrialni-tatehnoparki (accessed 07.07. 2019).

10. Vy`gidne vzayemodopovnennya yak krok vpered: analiz ry`nku ekotexnoparkiv v 20172019 rr. [Beneficial complementarity as a step forward: analysis of the market of ecotechnology parks in 2017-2019] Proconsulting.ua (n. d.). Available at: https://pro-consulting.ua/ua/pressroom/ vygodnoe-vzaimodopolnenie-kak-shagvpered-analiz-rynka-ekotehnoparkov-v2017-2019-gg (accessed 07.07. 2019).

11. Pro naukovu i naukovo-texnichnu diyal'nist': Zakon Ukrayiny', redakciya vid 19.04.2020 [On scientific and scientific-technical activity: Law of Ukraine, edition of 19.04.2020]. Available https://zakon.rada.gov.ua/laws/show/84819\#Text (accessed 08.07. 2019).

12. Pro sxvalennya Strategiyi rozvy'tku sfery innovacijnoyi diyal'nosti na period do 2030 roku : Rozporyadzhennya kabinetu ministriv Ukrayiny` vid 10 ly`pnya 2019 r. \# 526-r. [On approval of the Strategy for the development of innovation for the period up to 2030: Order of the Cabinet of Ministers of Ukraine of July 10, 2019 № 526-r.] Available at: https://zakon.rada.gov.ua/laws/show/5262019-r\#Text (accessed 14.07. 2019).

13. T.V. Py`sarenko, T.K. (2019). Kvasha Stan innovacijnoyi diyal'nosti ta diyal'nosti u sferi transferu texnologij v Ukrayini u 2018 roci. Anality'chna dovidka. [The state of innovation and technology transfer activities in Ukraine in 2018. Analytical reference]. Ky yiv, UkrINTEl. Available at: https://mon.gov.ua/storage/app/media/inn ovatsii-transfertehnologiy/2019/07/03/stan-innov-diyaln2018f.pdf. (accessed 11.07. 2019). 